\author{
Citation: Ajdarovska, Z. \& Attar, M., Analysing The Relationship Between Organizational \\ Culture And Organizational Ambidexterity, BMIJ, (2020), 8(3): 3550-3581, doi: \\ http://dx.doi.org/10.15295/bmij.v8i3.1534
}

\title{
ANALYSING THE RELATIONSHIP BETWEEN ORGANISATIONAL CULTURE AND ORGANISATIONAL AMBIDEXTERITY
}

Zejnepe AJDAROVSKA 1

Melis ATTAR 2

\author{
Received Date (Başvuru Tarihi): \\ Accepted Date (Kabul Tarihi): \\ Published Date (Yayın Tarihi):
}

$3 / 06 / 2020$

$23 / 08 / 2020$

$25 / 09 / 2020$

In the article, the first author is in the role of the Corresponding Author.

\begin{abstract}
Keywords:

Organizational Culture,

Organisational Ambidexterity
\end{abstract}

JEL Codes:

M10, M14, M16

Nowadays, despite the increased number of investigations on organisational ambidexterity in business environment, theoretical and practical literature still face a gap, and there is a lack of phenomenon construction. Besides, the organisational culture is a variable that has been studied for an extended period by many researchers from different fields. However, so far in the literature, the investigation of the relationship between organisational culture and organisational ambidexterity is rare and not exclusive. In this regard, this study is original in that it attempts to examine the relationship between organisational culture and organisational ambidexterity, as well as exploring the effect of the former on the latter in two companies that operate in the same sector but in two different countries - Turkey and North Macedonia, thus allowing a room for comparative analysis as well. The results indicate that the effect of organisational culture on organisational ambidexterity is significant and positive. Also, findings show that organisational culture plays a principal and decisive role in the exploration and exploitation strategy of organisational ambidexterity.

\section{ÖRGÜT KÜLTÜRÜ VE ÖRGÜTSEL USTALIK ARASINDAKİ İLIŞKİNINN INCELENMESI}

\begin{abstract}
$\ddot{O Z Z}$
Anahtar Kelimeler:

Örgütsel Kültür,

Örgütsel Ustalık

JEL Kodlar:

M10, M14, M16

Günümüzde, iş ortamında örgütsel ustalı̆̆a ilişkin artan sayıda incelemeye rağmen, teorik ve pratik literatür hala bir boşlukla karşı karşıyadır ve kavramın tanımlanması konusunda eksikler olduğu göze çarpmaktadır. Ayrıca, örgüt kültürü, farklı alanlardan birçok araştırmacı tarafindan uzun süredir incelenen bir değişken olmasına rağmen, literatürde şimdiye kadar örgüt kültürü ile örgütsel ustalık arasındaki ilişkinin araştırılmasına ait çalışmaların nadir olduğu görülmektedir. Bu bağlamda, çalışmanın, örgüt kültürü ile örgütsel ustalık arasındaki ilişkiyi incelemesinin yanı sıra iki kavram arasındaki ilişkiyi Türkiye ve Kuzey Makedonya' daki iki benzer sektörde faaliyet gösteren şirkette karşılaştırmalı uygulaması açısından da özgün olduğu söylenebilir. Sonuçlar, örgüt kültürünün örgütsel ustalı üzerindeki etkisinin anlaml ve olumlu olduğunu göstermektedir. Ek olarak, bulgular örgüt kültürünün örgütsel ustalı̆̆ın araştırma ve faydalanma stratejileri boyutlarında da temel ve belirleyici rol oynadığı yönündedir.
\end{abstract}

\footnotetext{
${ }^{1}$ Assistant of CEO, Halk Insurance SKOPJE, zejnepe.ajdarovska@outlook.com,

${ }^{2}$ Assistant Prof.Dr, Selçuk University, melisattar@selcuk.edu.tr,
} 


\section{INTRODUCTION}

Nowadays, globalisation of the world markets, increasing dynamism, increased customer desires that are in the process of constant change and development and increased needs for innovation all force the organisations to be agile, creative, flexible, and ambidextrous to identify strategic alternatives for survival. One of these alternatives can be put as an organisational ambidexterity strategy which in recent years is frequently highlighted by both researchers and practitioners in the field (Chen et al., 2016: 920). Thus, organisational ambidexterity implies the exploitation of the existing competencies and exploration of innovative ideas of the organisation (Pellegrinelli et al., 2015: 155). Of late, the concept of ambidexterity is viewed as a necessary tool since organisations want to survive not only in the short term but also in the long-term (Sulphey and Alkahtani, 2017: 339).

On the other hand, organisations continue to gain the competitive edge in terms of their products and services apply the organisational culture which intervenes the interaction between the individual and the organisational level, defines the basic presumptions after that knowledge is managed and shared and suggests who is expected to control and share the transferred knowledge (Wei and Miraglia, 2017: 572). Consequently, organisational culture incorporates the desires, experiences, and values of an organisation and is reflected in itself, internal works, in cooperation with outside the organisation and future expectations. Thus all of these keep the organisation together and well-balanced (Hogan and Coote, 2014: 1609; Klimas, 2016: 92; Larentis et al., 2018: 39).

Considering that members of the companies in Turkey and Republic of North Macedonia spent about 40 hours in the work environment, there is enough room to consider that their organisation's culture appears to influence their work life and their personal life. Hence, the culture and ambidexterity in the organisational level can play a varied role in each process of development but continuously adapt and co-assess each other under the direction of strategic orientation. Considering this, international and national studies on the concept of organisational ambidexterity are taking a new spot in the literature and are somewhat limited. In Turkey, in recent years, the concept 
gets attention, but the definition of the concept has not yet fully settled. Similarly, the notion of organisational ambidexterity is still unknown and unexplored in the Republic of North Macedonia.

Consequently, considering that organisations to survive and excel in business environments they build and foster the capability to innovate this study is important and original in terms of an in-depth examination of the relationship between the organisational culture and organisational ambidexterity. Besides, to the best of the knowledge, the current level of organisational ambidexterity in the food industry has not been investigated, which means that our research is quantum satis investigation. In the literature, studies on the organisational ambidexterity seem to focus on the idea of culture; however, it is difficult to assert that it is studied sufficiently. Given the fact that scope of this study involves Turkey and Republic of North Macedonia, the researchers analysed above show that there is no research in Republic of North Macedonia so far, whereas there is only one single study in Turkey which was carried out by Findiklı and Pinar (2014).

\section{CONCEPTUAL FRAMEWORK}

\subsection{The Concept and Scope of Organizational Culture}

By relying on hypotheses of anthropologists, sociologists, and social psychologists, scholars have attempted various endeavours to find and to comprehend the nearby connections among culture, the conduct and states of people and groups in organisations utilising cultural ideas, for example, language or dialects, rituals, semiotics, stories, and ceremonies (O'Reilly et al., 1991: 491; Warrick, 2017: 395). These cultural ideas which have changed over time have recognised how workers see their reality and react to it (Ahmady et al., 2016: 388). The assortment of organisational culture has got huge research consideration into the organisational analysis in the late 1970s and 1980s (Lu et al., 2016: 94; Maitland et al., 2015: 502; Schein, 1988: 408) and organisational scholars have been engaged with the role of culture in an organisational lifetime by a progression of well-known books, scholastic gatherings, particular issues of academic journals and some evaluations have brought more than 4600 articles on the subject (Chatman and O'Reilly, 2016: 200). 
Furthermore, the literature affirms the idea that there exist numerous meanings for organisational culture (Hogan and Coote, 2014: 1610), notwithstanding, organisational culture broadly alludes to organisational values acknowledged by the majority of workers and in standard norms and beliefs of organisation's individuals (Vukonjanski and Nikolić, 2013: 41). Agreeing, from an inner viewpoint, values are depicted as the most critical component of culture because reflecting on human conduct (Urban, 2015: 729), while beliefs dwell inside of employees and derive as a matter of fact regarding the proper conduct to manage diverse occasions (Dubey et al., 2017: 60). As the organisation's structures and frameworks specifically impact such, norms and expectations, and also, by the abilities of workers (Rovithis et al., 2017: 9). This definition of organisational culture clarifies that the culture not only characterises the respective representatives, clients, providers, and rivals but also characterises how an organisation will collaborate with these main components (Barney, 1986: 657). The manifestation of all these feelings represents that the culture in an organisation is conjectured to be the prime factor of holding organisational techniques, the unification of organisational skills into cohesiveness, giving answers for the issues encountered by the corporation, and, preventing or encouraging the corporation's accomplishment of its objectives (Yilmaz and Ergun, 2008: 291).

\subsubsection{Organisational Culture Models}

Organisational culture has become a measurable variable since culture plays a decisive component in the distant future of an effective organisation and different models can be found crosswise over various fields of investigating models (Dauber et al., 2012). One of them is Hofstede's Culture Model which emphasises that the term of culture can be related to the view of nations and organisations. Hofstede (1993), claims that national culture deals with the differences that exist between groups of nations or regions. On the other hand, organisational culture deals with differences that exist in practices between organisations or parts of the same organisation (sub-cultures) (Hofstede, 1983: 76). Hofstede's Culture Model involves four dimensions of national value differences such as considerable vs small power distance, substantial ws weak uncertainty avoidance, individualism vs collectivism, masculinity vs femininity (Hofstede 
and Bond, 1984: 419). As of late, Chinese researchers have uncovered a fifth significant dimension of culture called long-versus short-term orientation in addition to the other four (Hofstede, 1998: 480). Additionally, Bulgarian researcher Michael Minkov discovered a new calculation and the expansion of a sixth dimension named indulgence vs restraint (Hofstede et al., 2010: 45).

Another investigating model to measure the concept of organisational culture is Edgar Schein's Organizational Culture Model. They emphasise that culture is owned by the group and the general organisation may achieve culture on the off chance that it has been a sustainable group for some timeframe, and each subgroup of the organisation may achieve its own culture on the off chance that there is sustainability in its history. This model involves three levels, such as artefacts, espoused values, underlying assumptions (Schein, 2009: 134).

Additionally, Competing Values Framework (CVF) developed by Cameron and Quinn (2006) and is one of the models to measure organisational culture where its framework endeavours to inspect the values and beliefs to illuminate perspectives such as employees perceptions and opinions about their workplace (Giritli et al., 2006: 3).

The Competing Values Framework distinguishes four predominant organisational culture patterns, namely clan, adhocracy, hierarchy, and the market. These values are characterised by two noteworthy axes, such as the organic process and mechanistic processes (J. Lee et al., 2016: 465). The first axis represents the distinction amongst organisations that make progress toward sustainable practices and those organisations that endeavour to enable their followers to manage their particular practices (Gregory et al., 2009: 674). On the other hand, mechanistic processes axis mirrors the contradictory requirements made by the internal organisations and their external environment (Denison and Spreitzer, 1991: 5). To summarise their framework, a Clan Culture in the organisational theory is related to human resource development and act more in flexibility and change. In general, clan organisations much emphasise internal collaboration (Marín et al., 2016: 101). The Adhocracy Culture in the organisational framework put its attention to flexibility and is guided by the external 
environment. In adhocracy cultures, a critical presumption is that change encourages the creation and collection of new resources (Hartnell et al., 2011: 679). A Market Culture of an organisation is commonly oriented on the relationship toward external factors than on the inward structure of the organisation. In any case, this does not imply that the organisation may lose its internal control (Sánchez-Marín et al., 2015: 171). Lastly, the Hierarchical Culture tends to be the execution of controls and is additionally alluded to inside efficiency, consistency, coordination, and assessment of an organisation (Denison and Spreitzer, 1991: 6).

This model is to a great degree helpful in organisation because it integrates the various type of culture, leadership, competencies, effectiveness and make the interpretation of worker's autonomy, individuality and give them motives and encourage to take risks. So, this kind of model is considered as a wide assortment of organisational occurrence because authority construction is straightforward and each individual knows his task and responsibility (Cameron and Freeman, 1991: 45; Cameron and Quinn, 2006: 33).

\subsection{The Concept and Scope of Organizational Ambidexterity}

In the business cycle, reaching competitive advantage in turbulent and competitive markets requires organisations to be dexterous, innovative, adaptable and multifaceted in order to fill clients' needs and expectation. Thus, the concept of ambidexterity has emerged and with a passage of time became visible by scholars (Çömez et al., 2011: 77). Ambidexterity indeed implies the ability of people to use both of their hands with equal ease. Indeed, ambidexterity describes people who are neither "right-handed" nor "left-handed" (Bodwell and Chermack, 2010: 196). Thus, ambidexterity has been adopted by organisational scholars in order to develop the concept in organisational settings (Rosing et al., 2011: 957).

In the organisational conception, the origins of the term ambidexterity have been investigated in Robert Duncan's seminal paper. Duncan (1976) first introduced the notion of ambidexterity in the organisational structure. He depicts the "dual structures" which are utilised by numerous firms to manage activities that include diverse time horizons and managerial skills (Birkinshaw and Gupta, 2013: 288). Thus, 
organisational ambidexterity $(O A)$ is conceptualised as the ability to create and linking previous knowledge and ideas or these competencies through recombining them in new methods to create new configurations of exploration and exploitation (Şimşek et al., 2010: 276). Exploitation requires the entire organisation's concentration in order to achieve better results from existing solutions. It is the root of refinement, implementation, increasing productivity, efficiency, variance reduction and control (Lee et al., 2017: 118; O’Reilly and Tushman, 2008: 189). Exploration establishes an assortment of experience across discovery and investigation. As such, exploration suggests organisational behaviour which is related to risk-taking, experimentation and innovation (Dunlap et al., 2013: 4). Thus, explorative knowledge and competence aim to develop innovative channel distribution, new ideas, innovative products and services (Strese et al., 2016: 42).

Briefly speaking, the phenomenon of ambidexterity is not a new phenomenon (Rosing et al., 2011: 957). However, during the last 15 years, this topic has become a target for scholars which provided rich clarifications about how firms deal with double structures in the business environments (Vahlne and Jonsson, 2017: 58). In the management field, the number of studies on the ambidexterity expanded from under 10 in 2004 to 80 available research in 2009 and even more in 2018. Hence, this increased attention has added refinement and expansion on the current topic (Günsel et al., 2018; Koryak et al., 2018; Raisch et al., 2009; Siachou and Gkorezis, 2018). Its significance has been further notable within or outside the organisation involving the area of strategic management, innovation, organisational learning and organisational behaviour (Panagopoulos, 2016: 5) and the managerial significance of ambidexterity has been considered as a critical component in the improvement of organisational adaptation, performance and survival (Şimşek, 2009).

\section{RESEARCH METHODOLOGY}

\subsection{Methodology and Sampling of the Study}

In order to carry out the research objectives at the best possible level and to test the developed hypotheses, research is carried out by using the questionnaire. In this study, the questionnaire is constructed by taking into consideration the particulars specified by experts and the previous empirical studies in this field. The questionnaire 
is formed by utilising theoretical and practical literature on the concepts of organisational culture and organisational ambidexterity. Extensive research is done about the most commonly used method. During the formulation of the questionnaire, the relevant literature is examined, the recommendations of academicians and business managers are taken into consideration, and the topic is covered together with the expectations of the ambidexterity field.

The questionnaire is developed in three main parts. In the first part of the questionnaire, questions for determining demographic characteristics are included. In the second and third part, evaluations about the organisational ambidexterity and organisational culture were elaborated. In the second part of it, the questionnaire includes questions about the concept of organisational ambidexterity.

To measure organisational ambidexterity, the questionnaire developed by Lubatkin et al. (2006) is used. In general, the organisational ambidexterity questionnaire consists of 12 questions where the first 6 (six) questions represent exploration subdimension and the last 6 (six) questions belong to exploitation subdimension. This scale, which is also employed by various studies such as (Attar, 2015; Lubatkin et al., 2006; Wang and Rafiq, 2014) is preferred because it is a reliable and a valid scale according to literature and is the most used and cited scale in multiple research. Respective questions have been taken from the study of Cameron and Freeman (1991) and Cameron and Quinn (2006) to measure the organisational culture. Organisational culture is divided into 4 (four) types such as clan, adhocracy, market and hierarchy culture. Each type of culture contains 6 (six) questions, which amount to 24 questions in total. Various studies also employ this scale (Aktaş et al., 2011; Arditi et al., 2017; Klimas, 2016; Lee and Kramer, 2016; Marín et al., 2016; Naranjo Valencia et al., 2016) and it is a reliable and valid scale according to literature.

In the second and third parts of the questionnaire, alternative answers ranging from 1 (strongly disagree) to 5 (strongly agree) are located on a five-point Likert-type.

In this study, a pilot analysis process is carried out to give the final form to the questionnaire prepared by evaluating the research with its aims and hypotheses. In this context, the questionnaire is examined by academicians who are experts in 
management and business field, and their suggestions are taken in the context of the development and improvement of the questionnaire. For the pilot study are involved employees of the food industry where 20 of them are involved in the Turkish company and 25 in Macedonian company. The results show that there is no confusion and doubt about the questionnaire that is used in the study and that the questions are understandable. The pilot survey data are analysed in SPSS 15.0, and the questionnaire is considered reliable.

By the purpose of the research, the universe of this study is constituted by the employees who work in the food industry in Turkey and North Macedonia. The population in Turkey is about 300, and about 220 hardcopy questions were distributed to employees, of them the 180 returned and after deleting the incomplete response, a final sample is 160 employees. The population in Macedonia is about 500, where 270 hardcopy questionnaire is distributed, but the final sample in this study is 200 employees.

The surveys were carried out from May 2017 to February 2018, and ethics committee permission document for this research is not required. After the examinations, 20 questionnaire forms conducted in the Turkish company were decided to be excluded due to various deficiencies, which resulted in a total number of 160 questionnaire forms to be taken into consideration. For the Macedonian part of the study, among the 200 questionnaires, 25 of them was considered as having high missing values or not reliable. In the determination of the sample population, the table of possible sample population figures representing a certain central mass, prepared by (Yazıcıoğlu and Erdoğan, 2004) is used. In this context, for the main population of 300 people for the Turkish company, the sample mass is calculated as 130 with $\pm 0,05$ sampling error, and for the Macedonian company, the sample mass is calculated as 180 for the main population of 500 people, with $\pm 0,05$ sampling error. So, it can well be said that the obtained sample has the power to represent the main population. During determining the participants to be included in the sampling of the study, a random sampling method was preferred (Nakip, 2013). 
The data collected in the research have been coded and transferred to the computer, and analyses of the data have been performed by utilising specific packet programs. The data gained from the study is coded and loaded into the 'SPSS 15.0' software, and the statistical tests to be used in the data analysis are determined after the data entry. The analyses employed to evaluate the data obtained from the research and to test the hypotheses are as follows: demographic analysis, reliability analysis, correlation analysis, regression analysis and Student' s-T test.

\subsection{Hypothesis of the Study}

Based on the literature review in the preceding section, a research model developed for the current study is indicated in Figure 1.

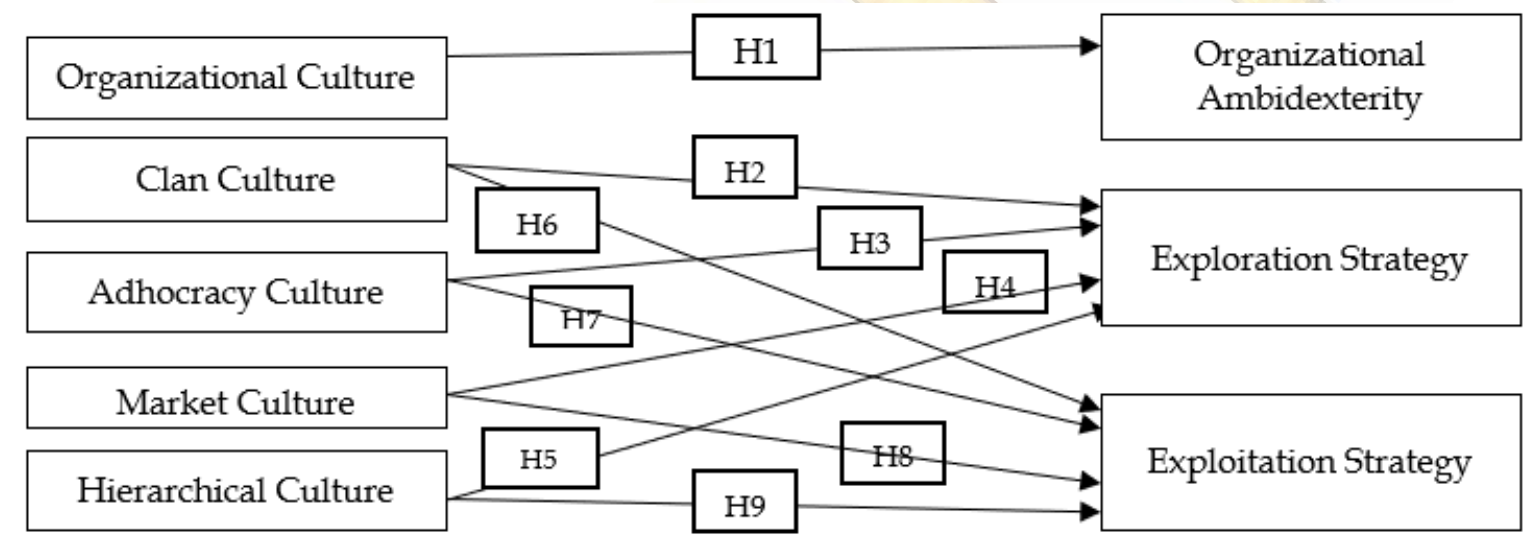

Figure 1. The Model and Hypotheses of Study

The model illustrates the relationship between organisational culture and organisational ambidexterity where organisational culture variable with its four dimensions such as clan, adhocracy, market and hierarchy culture is considered as the independent variable and organisational ambidexterity with its two dimensions (exploration and exploitation) as the dependent variable.

Accordingly, the hypotheses of the study are put in order as follows:

Hypothesis 1: Organisational culture has a positive relationship with organisational ambidexterity. 
Hypothesis 2: The Clan Culture, which is the sub-dimension of the organisational ambidexterity, has a positive relationship with the exploration strategy.

Hypothesis 3: The Adhocracy Culture, which is the sub-dimension of the organisational ambidexterity, has a positive relationship with the exploration strategy.

Hypothesis 4: The Market Culture, which is the sub-dimension of the organisational ambidexterity, has a positive relationship with the exploration strategy.

Hypothesis 5: The Hierarchical culture, which is the sub-dimension of the organisational ambidexterity, has a positive relationship with the exploration strategy.

Hypothesis 6: The Clan Culture, which is the sub-dimension of the organisational ambidexterity, has a positive relationship with the exploitation strategy.

Hypothesis 7: The Adhocracy Culture, which is the sub-dimension of organisational ambidexterity, has a positive relationship with the exploitation strategy.

Hypothesis 8: The Market Culture, which is the sub-dimension of organisational ambidexterity, has a positive relationship with the exploitation strategy.

Hypothesis 9: The Hierarchical Culture, which is the sub-dimension of organisational ambidexterity, has a positive relationship with the exploitation strategy.

\section{FINDINGS OF THE STUDY}

\subsection{Demographic Characteristics of the Participants in Turkey and North} Macedonia

In this section, first, the results of the demographic characteristics of the participants at the Turkish and North Macedonia company are presented. The following table depicted the demographic features of the participants. 
Table 1. Demographic Characteristics of the Participants in Turkey and Macedonia Research

\begin{tabular}{|c|c|c|}
\hline Characteristics & $\begin{array}{l}\text { Turkey } \\
(n=160)\end{array}$ & $\begin{array}{l}\text { Macedonia } \\
(n=200)\end{array}$ \\
\hline \multicolumn{3}{|l|}{ Gender } \\
\hline Male & $101(63,1)$ & $130(65)$ \\
\hline Female & $59(36,9)$ & $70(35)$ \\
\hline \multicolumn{3}{|l|}{ Marital Status } \\
\hline Married & $110(68,8)$ & $114(57)$ \\
\hline Single & $50(31,2)$ & $86(43)$ \\
\hline \multicolumn{3}{|l|}{ Age } \\
\hline 18-24 & $12(7,5)$ & $21(10,5)$ \\
\hline $25-35$ & $66(41,2)$ & $95(47,5)$ \\
\hline $36-50$ & $69(43,1)$ & $77(38,5)$ \\
\hline $50-65$ & $13(8,1)$ & $7(3,5)$ \\
\hline \multicolumn{3}{|l|}{ Education Level } \\
\hline Secondary School & $2(1,2)$ & - \\
\hline High School & $19(11,9)$ & $64(32)$ \\
\hline Vocational High School & $19(11,9)$ & - \\
\hline Associate Degree & $27(16,9)$ & - \\
\hline Bachelor Degree & $76(47,5)$ & $112(56)$ \\
\hline Master / Phd Degree & $17(10,6)$ & $24(12)$ \\
\hline \multicolumn{3}{|c|}{$\begin{array}{l}\text { Work Experience of participants } \\
\text { working in "Selva company" / "Dauti-Komerc company" }\end{array}$} \\
\hline Less than 1 year & $18(11,2)$ & $27(13,5)$ \\
\hline $1-3$ & $33(20,6)$ & $53(26,5)$ \\
\hline $4-6$ & $33(20,6)$ & $61(30,5)$ \\
\hline 7-9 & $32(20)$ & $36(18)$ \\
\hline More than 10 ye & $44(27,5)$ & $23(11,5)$ \\
\hline \multicolumn{3}{|l|}{ Position of Work } \\
\hline Chef / Supervisor & $22(13,8)$ & 38 (19) \\
\hline Manager of Department & $12(7,5)$ & $11(5,5)$ \\
\hline Employee & $126(78,8)$ & $151(75,5)$ \\
\hline \multicolumn{3}{|c|}{$\begin{array}{l}\text { Total Work Experience of participants } \\
\text { in "Selva Company" / "Dauti-Komerc company" }\end{array}$} \\
\hline Less than 1 year & $7(4,4)$ & $12(6)$ \\
\hline $1-3$ & $17(10,6)$ & $29(14,5)$ \\
\hline $4-6$ & $28(17,5)$ & $60(30)$ \\
\hline $7-9$ & $32(20)$ & $45(22,5)$ \\
\hline More than 10 years & $76(47,5)$ & $54(27)$ \\
\hline Number of employees & $100-249$ & $250-499$ \\
\hline
\end{tabular}




\subsection{Reliability Analysis Results in Turkish and North Macedonia Scale}

Table 2. Reliability Analysis Results of the Organizational Ambidexterity Scale

\begin{tabular}{|c|c|c|c|c|c|c|c|c|}
\hline \multirow[b]{2}{*}{ Factor/Items } & \multicolumn{4}{|c|}{ Turkey } & \multicolumn{4}{|c|}{ Macedonia } \\
\hline & Mean & SD & $\begin{array}{l}\text { Item-Total } \\
\text { Correlation }\end{array}$ & $a$ & Mean & SD & $\begin{array}{l}\text { Item-Total } \\
\text { Correlation }\end{array}$ & $a$ \\
\hline Exploratory & 4.14 & 0.64 & & 0.771 & 4.06 & 0.71 & & 0.787 \\
\hline Q1 & 4.15 & 0.96 & 0.632 & & 4.10 & 0.99 & 0.521 & \\
\hline Q2 & 4.20 & 0.87 & 0.610 & & 4.16 & 0.87 & 0.531 & \\
\hline Q3 & 4.21 & 0.84 & 0.506 & & 3.98 & 0.97 & 0.599 & \\
\hline Q4 & \multicolumn{3}{|c|}{ Excluded ${ }^{\dagger}$} & & 4.03 & 1.00 & 0.646 & \\
\hline Q5 & 4.02 & 0.99 & 0.597 & & Exclud & $\mathrm{ed}^{\dagger}$ & & \\
\hline Q6 & 4.14 & 0.75 & 0.585 & & 4.03 & 0.99 & 0.526 & \\
\hline Exploitation & 4.14 & 0.63 & & & 3.99 & 0.72 & & 0.800 \\
\hline Q7 & 4.14 & 0.90 & 0.566 & & 4.01 & 0.95 & 0.506 & \\
\hline Q8 & 4.08 & 0.91 & 0.554 & & 4.00 & 1.00 & 0.516 & \\
\hline Q9 & 4.16 & 0.86 & 0.558 & & Exclud & $\mathrm{ed}^{\dagger}$ & & \\
\hline Q10 & 4.06 & 0.92 & 0.586 & & 3.89 & 0.94 & 0.622 & \\
\hline Q11 & 4.17 & 0.79 & 0.662 & & 4.01 & 0.98 & 0.656 & \\
\hline Q12 & 4.21 & 0.82 & 0.613 & & 4.04 & 0.94 & 0.617 & \\
\hline $\begin{array}{l}\text { Organisational } \\
\text { Ambidexterity Scale }\end{array}$ & 4.14 & 0.59 & & 0.882 & 4.02 & 0.65 & & 0.870 \\
\hline
\end{tabular}

Q: Question, SD: Standard deviation, $a$ : Cronbach's alpha reliability coefficient

$\dagger$ Items were excluded due to the weak item-total correlation $(<0.50)$

The items whose item correlation was below 0.50 were excluded from the analysis, and the values were recalculated (Hair et al., 2006; Nunnally, 1978).

In the table above the reliability analysis are presented. According to the results of the organisational ambidexterity in Turkish scale and its sub-dimensions, consisting of 12 items and 2 factors in total, as far as 6 items constituting the exploratory subdimension, which is one of the organisational ambidexterity scale sub-dimensions, are considered, the item no 4 is excluded from the analysis because its total correlation and squared multiple correlation values were low. The following, the general average for the exploratory sub-dimension is calculated as 4.14 , and the reliability of the subdimension as 0.771 . Besides, the mean and standard deviation values for all the items in the sub-dimension are given in Table 2. The general average for the exploitation sub-dimension is calculated as 4.14 and the reliability coefficient as 0.822 . The general average for the organisational ambidexterity scale is calculated as 4.14 and the reliability as 0.882 . In the analysis related to organisational ambidexterity, the item no 4 is excluded from the scale and the analysis continued in this way. 
According to the reliability analysis results of the organisational ambidexterity and its sub-dimensions of employees working in the North Macedonia company, consisting of 12 items and 2 factors in total, as far as 6 items constituting the exploratory sub-dimension, which is one of the organisational ambidexterity scale subdimensions, are considered, the item no 5 is excluded from the analysis because its item-total correlation and squared multiple correlation values were low. The general average for the exploratory sub-dimension is calculated as 4.06 and its reliability as 0.787. In Table 2 are given the mean and the standard deviation values for all the items in the sub-dimension. Likewise, when 6 items in the exploitation sub-dimension of the organisational competence scale are analysed, and the item no 9 is excluded from the analysis because its total correlation and squared multiple correlation values are low. The general average for the exploitation sub-dimension is calculated as 3.99 and its reliability coefficient as 0.800 . The general average for the organisational ambidexterity scale is calculated as 4.02 and its reliability as 0.870 . In analyses related to organisational ambidexterity, items no 5 and no 9 are excluded from the scale, and the analyses continued in this way.

The items whose item correlation was below 0.50 were excluded from the analysis, and the values were recalculated (Hair et al., 2006; Nunnally, 1978).

According to the results of the reliability analysis of the organisational culture Turkish scale and its sub-dimensions, consisting of 24 items and 4 factors in total, when 6 items constituting the clan sub-dimension, which is one of the organisational culture scale sub-dimensions, are analysed, the general average for the clan sub-dimension is calculated as 4.05 and the sub-dimension reliability as 0.884 . Also, the median and standard deviation values for all the items in the sub-dimension are given in Table 3. Similarly, when 6 items in the adhocracy sub-dimension, which is one of the subdimensions of the organisational culture scale, are analysed, the items no 11 and 12 are excluded from the analysis because their total correlation and squared multiple correlation values were low. The general average for the adhocracy sub-dimension is calculated as 4.01 and its reliability coefficient as 0.775 . Analysis of the 6 items in the market sub-dimension calculates the sub-dimension average as 4.07 and its reliability value as 0.827 . The average of hierarchy sub-dimension is calculated as 4.10 and its 
reliability coefficient as 0.824 . The general average for the organisational culture scale is calculated as 4.06, and the reliability coefficient as 0.940. Regarding the organisational culture, the analysis is consummated by excluding the items no 11 and 12 from the scale.

Table 3. Reliability Analysis Results of Organizational Culture Scale

\begin{tabular}{|c|c|c|c|c|c|c|c|c|}
\hline \multirow[b]{2}{*}{ Factor/Items } & \multicolumn{4}{|c|}{ Turkey } & \multicolumn{4}{|c|}{ Macedonia } \\
\hline & Mean & SD & $\begin{array}{l}\text { Item-Total } \\
\text { Correlation }\end{array}$ & $a$ & Mean & SD & $\begin{array}{l}\text { Item-Total } \\
\text { Correlation }\end{array}$ & $a$ \\
\hline Clan & 4.05 & 0.74 & & 0.884 & 3.88 & 0.72 & & 0.810 \\
\hline Q1 & 4.04 & 0.96 & 0.719 & & 3.95 & 0.95 & 0.545 & \\
\hline Q2 & 4.06 & 0.96 & 0.733 & & 3.78 & 1.01 & 0.578 & \\
\hline Q3 & 4.06 & 0.93 & 0.726 & & 3.97 & 1.00 & 0.591 & \\
\hline Q4 & 4.08 & 0.83 & 0.707 & & 3.94 & 1.00 & 0.608 & \\
\hline Q5 & 4.08 & 0.89 & 0.669 & & 3.90 & 1.02 & 0.516 & \\
\hline Q6 & 4.02 & 0.96 & 0.631 & & 3.76 & 1.06 & 0.579 & \\
\hline Adhocracy & 4.01 & 0.72 & 3 & & 3.85 & 0.75 & & 0.764 \\
\hline Q7 & 3.83 & 0.99 & 0.528 & & 3.75 & 1.11 & 0.533 & \\
\hline Q8 & 4.05 & 0.95 & 0.584 & & 3.90 & 1.07 & 0.525 & \\
\hline Q9 & 4.09 & 0.90 & 0.624 & & 3.93 & 1.00 & 0.529 & \\
\hline Q10 & 4.08 & 0.88 & 0.581 & & Exclud & $\mathrm{ed}^{\dagger}$ & & \\
\hline Q11 & \multicolumn{2}{|c|}{ Excluded ${ }^{\dagger}$} & & & 3.78 & 1.04 & 0.551 & \\
\hline Q12 & \multicolumn{2}{|c|}{ Excluded ${ }^{\dagger}$} & & & 3.90 & 1.04 & 0.529 & \\
\hline Market & 4.07 & 0.63 & & 0.827 & 3.96 & 0.72 & & 0.778 \\
\hline Q13 & 4.06 & 0.81 & 0.524 & & Exclud & $\mathrm{ed}{ }^{\dagger}$ & & \\
\hline Q14 & 4.06 & 0.88 & 0.640 & & 3.90 & 0.99 & 0.570 & \\
\hline Q15 & 4.07 & 0.88 & 0.631 & 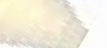 & 3.97 & 1.07 & 0.615 & \\
\hline Q16 & 4.02 & 0.84 & 0.532 & & 4.04 & 0.94 & 0.567 & \\
\hline Q17 & 4.14 & 0.83 & 0.654 & & 3.90 & 0.99 & 0.579 & \\
\hline Q18 & 4.06 & 0.89 & 0.594 & & 3.98 & 0.95 & 0.543 & \\
\hline Hierarchy & 4.10 & 0.61 & & 0.824 & 3.97 & 0.76 & & 0.744 \\
\hline Q19 & 4.15 & 0.82 & 0.526 & & Exclud & $\mathrm{ed}^{\dagger}$ & & \\
\hline Q20 & 4.04 & 0.88 & 0.590 & & 3.98 & 1.06 & 0.540 & \\
\hline Q21 & 4.04 & 0.89 & 0.564 & & 3.92 & 0.96 & 0.568 & \\
\hline Q22 & 4.08 & 0.84 & 0.608 & & Exclud & $\mathrm{ed}^{\dagger}$ & & \\
\hline Q23 & 4.14 & 0.78 & 0.624 & & 3.96 & 1.03 & 0.511 & \\
\hline Q24 & 4.13 & 0.83 & 0.642 & & 4.04 & 0.98 & 0.535 & \\
\hline $\begin{array}{l}\text { Organisational } \\
\text { Culture Scale }\end{array}$ & 4.06 & 0.59 & & 0.940 & 3.92 & 0.65 & & 0.929 \\
\hline
\end{tabular}

The reliability analysis results of the organisational culture North Macedonia scale and its sub-dimensions are consisting of 24 items and 4 dimensions in total. According to the findings, when 6 items constituting the clan sub-dimension, which is one of the organisational culture scale sub-dimensions, are analysed, the overall average of the clan sub-dimension is calculated as 3.88 and the sub-dimension reliability as 0.810 . In 
Table 3 are given the mean and standard deviation values for all the items in the subdimension. Likewise, when 6 items in the adhocracy sub-dimension, which is one of the sub-dimensions of the organisational culture scale, are analysed, the item no 10 is excluded from the analysis because its total correlation and squared multiple correlation values are low. The general average for the adhocracy sub-dimension is calculated as 3.85 and its reliability coefficient as 0.764 . When the 6 items in the market sub-dimension are analysed, the item no 13 is excluded from the analysis due to the same reason. After this item is excluded from the analysis, the sub-dimension average is calculated as 3.96 and its reliability value as 0.778 . For the hierarchy sub-dimension, the questions no 19 and no 22 are excluded from the analysis because of the same justification. Following the exclusion, the sub-dimension average is calculated as 3.97 and its reliability coefficient as 0.744 . The general average for the organisational culture scale is calculated as 3.92 and its reliability as 0.929 . In the analysis related to the organisational culture, the items no 10,13, 19 and 22 are excluded from the scale, and the analysis continued accordingly.

\subsection{Results of Correlation Analysis in Turkish and Macedonia Scale}

Table 4. Results of Correlation Analysis on the Organizational Culture Scale and Its Sub-dimensions and the Organizational Ambidexterity Scale and its Sub-Dimensions

\begin{tabular}{cccc}
\hline & Organisational Ambidexterity & Exploratory & Exploitation \\
\hline $\begin{array}{c}\text { Organizational Culture } \\
\text { Turkey }\end{array}$ & $0.712^{* * *}$ & $0.673^{* * *}$ & $0.660^{* * *}$ \\
Macedonia & $0.772^{* * *}$ & $0.689^{* * *}$ & $0.729^{* * *}$ \\
Clan Culture & & \\
$\quad$ Turkey & $0.625^{* * *}$ & $0.598^{* * *}$ & $0.574^{* * *}$ \\
$\begin{array}{c}\text { Macedonia } \\
\text { Adhocracy Culture }\end{array}$ & $0.702^{* * *}$ & $0.609^{* * *}$ & $0.679^{* * *}$ \\
$\quad$ Turkey & $0.587^{* * *}$ & $0.571^{* * *}$ & $0.530^{* * *}$ \\
Macedonia & $0.691^{* * *}$ & $0.617^{* * *}$ & $0.652^{* * *}$ \\
Market Culture & & & \\
Turkey & $0.642^{* * *}$ & $0.615^{* * *}$ & $0.589^{* * *}$ \\
Macedonia & $0.703^{* * *}$ & $0.617^{* * *}$ & $0.672^{* * *}$ \\
Hierarchy Culture & & & \\
Turkey & $0.639^{* * *}$ & $0.575^{* * *}$ & $0.617^{* * *}$ \\
Macedonia & $0.630^{* * *}$ & $0.598^{* * *}$ & $0.559^{* * *}$ \\
\hline & $* * p<0.001$ & &
\end{tabular}

In this study, Spearman's Rho Correlation is used to measure the degree of association between two variables. Relationships between the organisational culture 
scale and its sub-dimensions, the organisational ambidexterity scale and its subdimensions are investigated with Spearman's rho correlation coefficient, and the respective findings are provided in Table 4 . According to these results, there is a significant and positive relationship between organisational culture perceptions and organisational ambidexterity perceptions of the participants in the Turkish company $(\mathrm{r}=0.712, \mathrm{p}<0.05)$.

The findings of North Macedonia of relationships between organisational culture scale and its sub-dimensions and organisational ambidexterity scale and its sub-dimensions are researched with Spearman's rho correlation coefficient are given in Table 4. According to these results, there is a significant and positive relationship between organisational culture perceptions and organisational ambidexterity perceptions of the participants in the study $(\mathrm{r}=0.772, \mathrm{p}<0.05)$.

\subsection{Turkey and North Macedonia Regression Analysis Results}

Table 5. Turkey and Macedonia Scale Regression Analysis Results

\begin{tabular}{|c|c|c|c|c|c|c|c|c|c|}
\hline $\begin{array}{l}\text { Dependent } \\
\text { Variable }\end{array}$ & $\begin{array}{l}\text { Independent } \\
\text { Variable }\end{array}$ & $B$ & $S E$ & Beta & & $p$ & $\begin{array}{l}F \\
(p)\end{array}$ & $\begin{array}{c}R^{2} \\
\left(\Delta R^{2}\right)\end{array}$ & $R$ \\
\hline \multicolumn{10}{|l|}{ Turkey } \\
\hline $\begin{array}{l}\text { Organisational } \\
\text { Ambidexterity }\end{array}$ & $\begin{array}{l}\text { Constant } \\
\text { Organizational } \\
\text { Culture }\end{array}$ & $\begin{array}{l}1.215 \\
0.721 \\
\end{array}$ & 0.056 & 0.712 & $\begin{array}{l}5.241 \\
12.760\end{array}$ & $\begin{array}{l}<0.001 \\
<0.001\end{array}$ & $\begin{array}{l}162.815 \\
(<0.001)\end{array}$ & $\begin{array}{c}0.508 \\
(0.504)\end{array}$ & 0.712 \\
\hline $\begin{array}{l}\text { Organisational } \\
\text { Ambidexterity }\end{array}$ & $\begin{array}{l}\text { Constant } \\
\text { Clan } \\
\text { Adhocracy } \\
\text { Market } \\
\text { Hierarchy }\end{array}$ & $\begin{array}{l}1.181 \\
0.198 \\
0.077 \\
0.273 \\
0.179 \\
\end{array}$ & $\begin{array}{l}0.239 \\
0.076 \\
0.077 \\
0.086 \\
0.096 \\
\end{array}$ & $\begin{array}{l}0.245 \\
0.094 \\
0.288 \\
0.185 \\
\end{array}$ & $\begin{array}{l}4.942 \\
2.603 \\
1.011 \\
3.173 \\
1.873 \\
\end{array}$ & $\begin{array}{r}<0.001 \\
0.010 \\
0.314 \\
0.002 \\
0.063 \\
\end{array}$ & $\begin{array}{c}40.539 \\
(<0.001)\end{array}$ & $\begin{array}{c}0.511 \\
(0.499)\end{array}$ & 0.715 \\
\hline $\begin{array}{l}\text { Macedonia } \\
\text { Organisational } \\
\text { Ambidexterity }\end{array}$ & $\begin{array}{l}\text { Constant } \\
\text { Organizational } \\
\text { Culture }\end{array}$ & 0.774 & 0.045 & 0.772 & $\begin{array}{l}5.549 \\
17.117\end{array}$ & $\begin{array}{l}<0.001 \\
<0.001\end{array}$ & $\begin{array}{l}292.981 \\
(<0.001)\end{array}$ & $\begin{array}{c}0.597 \\
(0.595)\end{array}$ & 0.772 \\
\hline $\begin{array}{l}\text { Organisational } \\
\text { Ambidexterity }\end{array}$ & $\begin{array}{l}\text { Constant } \\
\text { Clan } \\
\text { Adhocracy } \\
\text { Market } \\
\text { Hierarchy }\end{array}$ & $\begin{array}{l}0.996 \\
0.228 \\
0.203 \\
0.260 \\
0.083\end{array}$ & $\begin{array}{l}0.181 \\
0.072 \\
0.066 \\
0.070 \\
0.062\end{array}$ & $\begin{array}{l}0.251 \\
0.234 \\
0.287 \\
0.097\end{array}$ & $\begin{array}{l}.514 \\
3.169 \\
3.085 \\
3.744 \\
1.353\end{array}$ & $\begin{array}{r}<0.001 \\
0.002 \\
0.002 \\
<0.001 \\
0.177\end{array}$ & $\begin{array}{l}73.183 \\
(<0.001)\end{array}$ & $\begin{array}{c}0.600 \\
(0.592)\end{array}$ & 0.775 \\
\hline
\end{tabular}

The first line of Table 5 depicts the results of simple linear regression analysis and multiple regression analysis of Turkish scale conducted in order to capture how organisational culture and sub-dimensions predict organisational ambidexterity. 
Findings indicate that organisational culture perception of the participants in the survey is a significant predictor of organisational ambidexterity $(F=162.815, p<0.05)$. The organisational culture score explains $50 \%$ of the change in the organisational ambidexterity score. However, the test for the significance of the regression also shows that organisational culture score has a significant effect on organisational ambidexterity $(\mathrm{t}=12.760, \mathrm{p}<0.05)$.

When the results of multiple regression are analysed, it was seen that the model established is significant $(\mathrm{F}=40.539, \mathrm{p}<0.05) .49 .9 \%$ of the change in the organizational ambidexterity score is explained by independent variables. When the significance values of the regression coefficients are analysed, it is determined that Clan culture $($ Beta $=0.245, \mathrm{t}=2.603, \mathrm{p}<0.05)$ and Market culture $($ Beta $=0.288, \mathrm{t}=3.173, \mathrm{p}<0.05)$ have significant effects on organizational ambidexterity. In addition, it is found out that effects of Adhocracy culture (Beta $=0.094, t=1.011, p=0.314>0.05)$ and Hierarchy culture $($ Beta $=0.185, \mathrm{t}=1.873, \mathrm{p}=0.063>0.05)$ on organizational ambidexterity are not significant.

According to the findings in the second line which presents the North Macedonia scale, it can be observed that the organisational culture perception of the participants is a significant predictor of organisational ambidexterity $(F=292.981, p<0.05)$. The organisational culture score describes $59 \%$ of the change in the organisational ambidexterity score. However, according to the test for the significance of the regression coefficient also shows that the organisational culture score has a significant effect on organisational ambidexterity $(t=17.117, \mathrm{p}<0.05)$.

When the results of multiple regression are analyzed, it is seen that the model is significant $(\mathrm{F}=73.183, \mathrm{p}<0.05) .59 \%$ of the change in the organizational ambidexterity score is explained by independent variables. When the significance values of the regression coefficients are analyzed, it is determined that effects of Clan culture $($ Beta $=0.251, \mathrm{t}=3.169, \mathrm{p}=0.002<0.05)$, Adhocracy culture $($ Beta $=0.234, \mathrm{t}=$ 3.085, $\mathrm{p}=0.002<=3.744, \mathrm{p}<0.05)$ and Market culture (Beta=0.287, $\mathrm{t}=3.744, \mathrm{p}<0.05)$ on organizational ambidexterity are significant. Hierarchy culture (Beta $=0.097, t=1.353$, $p=0.177>0.05)$ is found to have no effect on organizational ambidexterity. 
Table 6. Turkey and Macedonia Scale Regression Analysis Results

\begin{tabular}{|c|c|c|c|c|c|c|c|c|c|}
\hline $\begin{array}{l}\text { Dependent } \\
\text { Variable }\end{array}$ & $\begin{array}{l}\text { Independent } \\
\text { Variable } \\
\end{array}$ & $B$ & $S E$ & Beta & $t$ & $p$ & $\begin{array}{l}F \\
(p)\end{array}$ & $\begin{array}{c}R^{2} \\
\left(\Delta R^{2}\right) \\
\end{array}$ & $R$ \\
\hline \multicolumn{10}{|l|}{ Turkey } \\
\hline \multirow{2}{*}{$\begin{array}{l}\text { Exploratory } \\
\text { Ambidexterity }\end{array}$} & Constant & 1.160 & 0.263 & & 4.402 & & \multirow{2}{*}{$\begin{array}{l}130.932 \\
(<0.001)\end{array}$} & \multirow{2}{*}{$\begin{array}{c}0.453 \\
(0.450)\end{array}$} & \multirow{2}{*}{0.673} \\
\hline & $\begin{array}{l}\text { Organizational } \\
\text { Culture }\end{array}$ & 0.735 & 0.064 & 0.673 & 11.443 & $<0.001$ & & & \\
\hline \multirow{5}{*}{$\begin{array}{l}\text { Exploratory } \\
\text { Ambidexterity }\end{array}$} & Constant & 1.160 & 0.271 & & 4.284 & $<0.001$ & \multirow{5}{*}{$\begin{array}{c}33.189 \\
(<0.001)\end{array}$} & \multirow{5}{*}{$\begin{array}{c}0.461 \\
(0.447)\end{array}$} & \multirow{5}{*}{0.679} \\
\hline & Clan & 0.215 & 0.086 & 0.247 & 2.495 & 0.014 & & & \\
\hline & Adhocracy & 0.121 & 0.087 & 0.136 & 1.393 & 0.166 & & & \\
\hline & Market & 0.228 & 0.098 & 0.329 & 3.460 & $<0.001$ & & & \\
\hline & Hierarchy & 0.062 & 0.108 & 0.059 & 0.570 & 0.569 & & & \\
\hline \multicolumn{10}{|l|}{ Macedonia } \\
\hline \multirow{2}{*}{$\begin{array}{l}\text { Exploratory } \\
\text { Ambidexterity }\end{array}$} & Constant & 1.129 & 0.222 & & & $<0.001$ & 179.085 & 0.475 & \multirow[b]{2}{*}{0.689} \\
\hline & $\begin{array}{l}\text { Organizational } \\
\text { Culture }\end{array}$ & 0.749 & 0.056 & 0.689 & 13.382 & $<0.001$ & $(<0.001)$ & $(0.472)$ & \\
\hline \multirow{5}{*}{$\begin{array}{l}\text { Exploratory } \\
\text { Ambidexterity }\end{array}$} & Constant & 1.125 & 0.224 & & 5.020 & $<0.001$ & \multirow{5}{*}{$\begin{array}{c}44.503 \\
(<0.001)\end{array}$} & \multirow{5}{*}{$\begin{array}{c}0.477 \\
(0.467)\end{array}$} & \multirow{5}{*}{0.691} \\
\hline & Clan & 0.145 & 0.089 & 0.147 & 1.628 & 0.105 & & & \\
\hline & Adhocracy & 0.222 & 0.081 & 0.236 & 2.725 & 0.007 & & & \\
\hline & Market & 0.195 & 0.086 & 0.198 & 2.260 & 0.025 & & & \\
\hline & Hierarchy & 0.187 & 0.077 & 0.200 & 2.448 & 0.015 & & & \\
\hline
\end{tabular}

The first line Table 6 shows the results of simple linear regression analysis and multiple regression analysis conducted in Turkish scale in order to determine how perceptions of organisational culture and its sub-dimensions of the participants in the study predict exploratory ambidexterity, which is a sub-dimension of organisational ambidexterity. Findings show that organisational culture perception of the participants in the survey is a significant predictor of exploratory ambidexterity $(\mathrm{F}=$ $130.392, \mathrm{p}<0.05)$. The organisational culture score explains $45 \%$ of the change in the exploratory ambidexterity score. On the other hand, the test for significance of regression coefficient also shows that the organisational culture score has a significant effect on exploratory ambidexterity $(\mathrm{p}<0.05)$.

The results of multiple regression analysis indicate that the model established is significant $(\mathrm{F}=33.189, \mathrm{p}<0.05) .46 \%$ of the change in the exploratory ambidexterity score is explained by the independent variables. When the significance values of the regression coefficients are analysed, it is determined that effects of Clan culture (Beta $=0.247, \mathrm{t}=2.495, \mathrm{p}=0.014<0.05)$ and Market culture $($ Beta $=0.329, \mathrm{t}=3.460, \mathrm{p}=0.001$ $<0.05$ ) on exploratory ambidexterity are significant. Further, it is found out that effects 
of Adhocracy culture (Beta $=0.136, t=1.393, p=0.166>0.05)$ and Hierarchy culture (Beta $=0.059, \mathrm{t}=0.570, \mathrm{p}=0.569>0.05)$ are not significant on exploratory ambidexterity.

In the other side, the second line of table 6 shows the results of simple linear regression analysis and multiple regression analysis of North Macedonia scale which determine how perceptions of organisational culture and its sub-dimensions of the participants in the study predict exploratory ambidexterity, which is a sub-dimension of organisational ambidexterity. According to the findings, it is seen that the perception of the organisational culture of the participants in the survey is a significant predictor of exploratory ambidexterity $(\mathrm{F}=179.085, \mathrm{p}<0.05)$. The organisational culture score explains $47 \%$ of the change in the exploratory ambidexterity score. However, the organisational culture score also has a significant effect on exploratory ambidexterity $(t=13.382, p<0.05)$, according to the test for the significance of the regression coefficient.

Regarding the results of multiple regression analysis, it is seen that the model is significant $(\mathrm{F}=44.503, \mathrm{p}<0.05) .47 \%$ of the change in the exploratory ambidexterity score is explained by the independent variables. When the significance values of the regression coefficients are analyzed, it is determined that effect of Clan culture (Beta $=0.147, \mathrm{t}=1.628, \mathrm{p}=0.105>0.05)$ on exploratory ambidexterity is not significant and effects of Adhocracy culture $($ Beta $=0.236, t=2.725, p=0.007<0.05)$ and Market culture (Beta $=0.198, \mathrm{t}=2.260, \mathrm{p}=0.025<0.05)$ on exploratory ambidexterity are significant. Hierarchy culture (Beta $=0.200, t=2.448, p=0.015>0.05)$ is found to have a significant effect on exploratory ambidexterity. 
Table 7. Turkey and Macedonia Scale Regression Analysis Results

\begin{tabular}{|c|c|c|c|c|c|c|c|c|c|}
\hline $\begin{array}{l}\text { Dependent } \\
\text { Variable }\end{array}$ & $\begin{array}{l}\text { Independent } \\
\text { Variable }\end{array}$ & $B$ & $S E$ & Beta & $t$ & $p$ & $\begin{array}{c}F \\
(p)\end{array}$ & $\begin{array}{c}R^{2} \\
\left(\Delta R^{2}\right) \\
\end{array}$ & $R$ \\
\hline \multicolumn{10}{|l|}{ Turkey } \\
\hline \multirow{2}{*}{$\begin{array}{l}\text { Exploitation } \\
\text { ambidexterity }\end{array}$} & Constant & 1.260 & 0.263 & & 4.789 & $<0.001$ & \multirow{2}{*}{$\begin{array}{l}122.172 \\
(<0.001)\end{array}$} & \multirow{2}{*}{$\begin{array}{c}0.436 \\
(0.432)\end{array}$} & \multirow{2}{*}{0.660} \\
\hline & $\begin{array}{l}\text { Organizational } \\
\text { Culture }\end{array}$ & 0.709 & 0.064 & 0.660 & 11.053 & $<0.001$ & & & \\
\hline \multirow{5}{*}{$\begin{array}{l}\text { Exploitation } \\
\text { ambidexterity }\end{array}$} & Constant & 1.199 & 0.271 & & 4.426 & $<0.001$ & \multirow{5}{*}{$\begin{array}{c}30.762 \\
(<0.001)\end{array}$} & \multirow{5}{*}{$\begin{array}{c}0.443 \\
(0.428)\end{array}$} & \multirow{5}{*}{0.665} \\
\hline & Clan & 0.184 & 0.086 & 0.215 & 2.133 & 0.035 & & & \\
\hline & Adhocracy & 0.041 & 0.087 & 0.047 & 0.475 & 0.635 & & & \\
\hline & Market & 0.220 & 0.098 & 0.218 & 2.251 & 0.026 & & & \\
\hline & Hierarchy & 0.277 & 0.108 & 0.269 & 2.554 & 0.012 & & & \\
\hline \multicolumn{10}{|l|}{ Macedonia } \\
\hline \multirow{2}{*}{$\begin{array}{l}\text { Exploitation } \\
\text { ambidexterity }\end{array}$} & Constant & 0.862 & 0.212 & & 4.070 & $<0.001$ & 224.112 & \multirow{2}{*}{$\begin{array}{c}0.531 \\
(0.529)\end{array}$} & \multirow[b]{2}{*}{0.729} \\
\hline & $\begin{array}{l}\text { Organizational } \\
\text { Culture }\end{array}$ & 0.799 & 0.053 & 0.729 & & $<0.001$ & $\begin{array}{l}(<0.001) \\
<0.001\end{array}$ & & \\
\hline \multirow{5}{*}{$\begin{array}{l}\text { Exploitation } \\
\text { ambidexterity }\end{array}$} & Constant & 0.868 & 0.211 & & 4.120 & $<0.001$ & 58.746 & \multirow{5}{*}{$\begin{array}{c}0.546 \\
(0.537)\end{array}$} & \multirow{5}{*}{0.739} \\
\hline & Clan & 0.311 & 0.084 & 0.313 & 3.705 & $<0.001$ & $(<0.001)$ & & \\
\hline & Adhocracy & 0.183 & 0.077 & 0.193 & 2.394 & 0.018 & 0.105 & & \\
\hline & Market & 0.326 & 0.081 & 0.328 & 4.019 & $<0.001$ & 0.007 & & \\
\hline & Hierarchy & $\begin{array}{c}- \\
0.020\end{array}$ & 0.072 & $\begin{array}{c}- \\
0.022\end{array}$ & 0.282 & 0.778 & $\begin{array}{l}0.025 \\
0.015\end{array}$ & & \\
\hline
\end{tabular}

The first line of Table 7 shows the results of simple linear regression analysis and multiple regression analysis performed in Turkish scale in order to demonstrate how perceptions of organisational culture and its sub-dimensions of the participants in the study predict the exploitation ambidexterity, which is a sub-dimension of organisational ambidexterity. According to the findings, it is seen that the organisational culture perception of the participants in the survey is a significant predictor of exploitation ambidexterity $(\mathrm{F}=122.172, \mathrm{p}<0.05)$. The organisational culture score explains $43 \%$ of the change in the exploratory ambidexterity score. However, the test for significance of the regression coefficient also shows that the organisational culture score has a significant effect on exploitation ambidexterity $(\mathrm{t}=$ 11.053, $\mathrm{p}<0.05)$.

When the results of multiple regression are analysed, it is observed that the model is significant $(\mathrm{F}=30.762, \mathrm{p}<0.05) .44 \%$ of the change in the exploitation ambidexterity score is explained by the independent variables. When the significance values of the regression coefficients are analysed, it is found that effects of Clan culture 
$($ Beta $=0.215, \mathrm{t}=2.133, \mathrm{p}=0.035<0.05)$, Market culture $($ Beta $=0.218, \mathrm{t}=2.251$, $\mathrm{p}=0.026<0.05)$ and Hierarchy culture (Beta $=0.269, \mathrm{t}=2.554, \mathrm{p}=0.0 .012<0.05)$ on exploitation ambidexterity are significant. Furthermore, it is found out that effect of Adhocracy culture $($ Beta $=0.047, \mathrm{t}=0.475, \mathrm{p}=0.635>0.05)$ on exploitation ambidexterity is not significant.

On the other hand, the second line of Table 7 shows the results of simple linear regression analysis and multiple regression analysis on North Macedonia scale in order to determine how participants' perceptions of organisational culture and its subdimensions predict exploitation ambidexterity, which is the sub-dimension of organisational ambidexterity. According to the findings, it is seen that the perception of the organisational culture of the participants in the survey is a significant predictor of exploitation ambidexterity ( $\mathrm{F}=224.112, \mathrm{p}<0.05)$. The organisational culture score explains $53 \%$ of the change in the exploitation ambidexterity score. However, the test for the significance of the regression coefficient also shows that the organisational culture score has a significant effect on exploitation ambidexterity $(t=14.97, p<0.05)$.

When the results of multiple regression are analyzed, it was seen that the model established is significant $(F=58.746, p<0.05) .54 \%$ of the change in exploitation ambidexterity score is explained by independent variables. When the significance values of the regression coefficients were analyzed, it was determined that Clan culture $($ Beta $=0.313, \mathrm{t}=3.705, \mathrm{p}=0.0 .001<0.05)$, Adhocracy culture $($ Beta=0.193, $\mathrm{t}=2.394, \mathrm{p}=0.018<0.05$ ), Market culture (Beta $=0.328, \mathrm{t}=4.019, \mathrm{p}=0.001<0.05$ ) have significant effects on exploitation ambidexterity. Hierarchy culture (Beta $=-0.022, \mathrm{t}=$ $0.282, \mathrm{p}=0.778>0.05)$ is found to have no significant effect on exploitation ambidexterity.

\subsection{Comparison of Organizational Ambidexterity and Organizational}

\section{Culture Scales and Sub-Dimensions According to Countries}

The differences in the organisational ambidexterity and organisational culture scales and subscale scores of the respondents according to the countries are analysed by Student' $\mathrm{s}-\mathrm{T}$ Test. In a statistical analysis for significance, $\mathrm{p}<0.05$ value is employed. 
Table 8. Comparison of Organizational Ambidexterity and Organizational Culture Scales and Sub-Dimensions According to Countries

\begin{tabular}{|c|c|c|c|c|c|c|}
\hline \multirow[b]{2}{*}{ Factor / Size } & \multicolumn{2}{|c|}{$\begin{array}{l}\text { Macedonia } \\
(\mathrm{n}=200)\end{array}$} & \multicolumn{2}{|c|}{ Turkey $(n=160)$} & \multirow[b]{2}{*}{$\mathrm{p}$} & \multirow[t]{2}{*}{$\begin{array}{c}\text { The significance } \\
\text { between } \\
\text { countries }\end{array}$} \\
\hline & Mean & SD & Mean & SD & & \\
\hline Explorative Strategy & 4.06 & 0.71 & 4.14 & 0.64 & 0.241 & \multirow{3}{*}{$\begin{array}{l}\text { Non- Significant } \\
\text { Significant } \\
\text { Non- significant }\end{array}$} \\
\hline Exploitation Strategy & 3.99 & 0.72 & 4.14 & 0.63 & 0.037 & \\
\hline $\begin{array}{l}\text { Organizational } \\
\text { Ambidexterity }\end{array}$ & 4.02 & 0.65 & 4.14 & 0.59 & 0.079 & \\
\hline Clan Culture & 3.88 & 0.72 & 4.05 & 0.74 & 0.027 & Significant \\
\hline Adhocracy Culture & 3.85 & 0.75 & 4.01 & 0.72 & 0.044 & Significant \\
\hline Market Culture & 3.96 & 0.72 & 4.07 & 0.63 & 0.133 & Non -significant \\
\hline Hierarchy Culture & 3.97 & 0.76 & 4.10 & 0.61 & 0.094 & Non -significant \\
\hline Organizational Culture & 3.92 & 0.65 & 4.06 & 0.59 & 0.025 & Significant \\
\hline
\end{tabular}

The differences in organisational ambidexterity and organisational culture scales and sub-dimensions, according to countries, are given in Table 8. Accordingly, the exploratory dimension perceptions of organisational ambidexterity subdimensions do not significantly differ according to the countries $(p=0.241>0.05)$. This would indicate that even though two companies operate in different locations and has its own set of guidelines, rules, policies and structures, they can share the same perceptions about the exploratory ambidexterity strategy. So, regardless of environmental conditions, both companies try to balance current strategies with the discovery of new ones. On the other hand, the exploitation of sub-dimension perceptions shows a significant change according to the countries $(p=0.037<0.05)$. While in Turkey, the exploitation sub-dimension perceptions of survey respondents are in an average of 4.14 , the exploitation perceptions of the North Macedonia participants were calculated with an average of 3.99, and exploitation perceptions of those surveyed in Turkey are significantly higher when compared to the Macedonians. Therefore, it can be assumed that maybe Turkish and North Macedonia Company manifest the existing resource, technologies, and capabilities in different techniques, strategies or systems. When the Organizational Ambidexterity scale is examined in general, there is no statistically significant difference between the general organisational ambidexterity perceptions of North Macedonia and Turkish participants $(p=0.079>0.05)$. Considering this, empirical contribution to this research 
suggests that even though members of organisations come from the different culture, background, tradition, beliefs, values and families they generally predict the same view about organisational ambidexterity. For clan culture from organisational culture sub-dimensions, there is a significant difference between participants' scores according to countries $(\mathrm{p}=0.027<0.05)$. Clan perceptions of Turkish participants are significantly higher than those of North Macedonia participants. Regarding the adhocracy sub-dimension, scores of Turkish participants are significantly higher than those of North Macedonia participants $(p=0.044<0.05)$. By this, it is assumed that the features of clan culture such as teamwork, participation, loyalty, mentoring, mutual trust and characteristic of adhocracy culture such as risk-taking, innovation, freedom, uniqueness are viewed differently in the location and the conditions in which employees operate. No significant difference is found between the perceptions of Turkish and Macedonian participants on Market $(\mathrm{p}=0.133>0.05)$ and Hierarchy perceptions $(p=0.094>0.05)$. Thus, this means that employees, despite the work environment, strive to fit into the Market and Hierarchy culture of the organisation where they operate. There is a statistically significant difference between organisational culture perception scores of North Macedonia and Turkish participants $(p=0.025<0.05)$. The average of the Turkish participants' organisational culture score (4.06) is found to be higher than the North Macedonia participants (3.92). Following this, it is gained that organisations from the different geographic territory around the world have in some special way their unique culture. Despite the utilisation of similar components in portraying a culture, each organisation has its way of treating common elements such as expectations, norms, experiences, psychological environment, behaviours, and values. 
Table 9. Summary of Research Findings in Turkey and North Macedonia

\begin{tabular}{|l|c|c|}
\hline \multicolumn{1}{|c|}{ HYPOTHESIS } & Results in Turkey & $\begin{array}{c}\text { Results in North } \\
\text { Macedonia }\end{array}$ \\
\hline $\begin{array}{l}\text { H1: Organisational culture has a positive relationship with } \\
\text { organisational ambidexterity. }\end{array}$ & ACCEPTED & ACCEPTED \\
\hline $\begin{array}{l}\text { H2: The Clan Culture has a positive relationship with the } \\
\text { exploration strategy, which is the sub-dimension of the } \\
\text { organisational ambidexterity. }\end{array}$ & ACCEPTED & ACCEPTED \\
\hline $\begin{array}{l}\text { H3: The Adhocracy Culture has a positive relationship with } \\
\text { the exploration strategy, which is the sub-dimension of the } \\
\text { organisational ambidexterity. }\end{array}$ & ACCEPTED & ACCEPTED \\
\hline $\begin{array}{l}\text { H4: } \text { The Market Culture has a positive relationship with the } \\
\text { exploration strategy, which is the sub-dimension of the } \\
\text { organisational ambidexterity. }\end{array}$ & ACCEPTED & ACCEPTED \\
\hline $\begin{array}{l}\text { H5: The Hierarchical culture has a positive relationship with } \\
\text { the exploration strategy, which is the sub-dimension of the } \\
\text { organisational ambidexterity. }\end{array}$ & ACCEPTED \\
\hline $\begin{array}{l}\text { H6: The Clan Culture has a positive relationship with the } \\
\text { exploitation strategy, which is the sub-dimension of } \\
\text { organisational ambidexterity. }\end{array}$ & ACCEPTED & ACCEPTED \\
\hline $\begin{array}{l}\text { H7: The Adhocracy Culture has a positive relationship with } \\
\text { the exploitation strategy, which is the sub-dimension of } \\
\text { organisational ambidexterity. }\end{array}$ & ACCEPTED \\
\hline $\begin{array}{l}\text { H8: The Market Culture has a positive relationship with the } \\
\text { exploitation strategy, which is the sub-dimension of } \\
\text { organisational ambidexterity. }\end{array}$ & ACCEPTED & ACCEPTED \\
\hline $\begin{array}{l}\text { H9: The Hierarchical Culture has a positive relationship with } \\
\text { the exploitation strategy, which is the sub-dimension of } \\
\text { organisational ambidexterity. }\end{array}$ & ACCEPTED & ACCEPTED \\
\hline
\end{tabular}

\section{CONCLUSION}

Globalisation and rapid technological developments have given rise to a very competitive and challenging business environment. Leaders and managers of the organisations in this contemporary development may use the culture as a unique source to fit the organisational characteristics in order to develop and enhance its competitive and innovative advantage.

The findings predicted and support a research hypothesis that organisational culture and its perceptions affect positively and significantly the organisational ambidexterity. The discoveries of our study provide the empirical support to the proposition by Yu et al. (2014) where note that these two variables continuously adapt and co-evaluate each other under the direction of strategic orientation. Besides, it emphasises that in an organisation, the role of organisational culture and the role of ambidextrous innovation ability can be different in each cycle of development. To 
understand better the composition of this field, the study of Lin and McDonough III (2011) discovered that in an organisation, the innovation process is immensely impacted by organisational culture. Additionally, findings indicate that the innovating process occurs and is completed by employees who are initiated by organisations. Thus, this context may serve as a basis for innovation. Additionally, the investigation carried out by Findıklı and Pinar (2014), indicate that there is a positive and meaningful relationship between organisational culture and organisational ambidexterity involving the exploitation and exploration activities.

Nevertheless, Büschgens et al. (2013) suggest that clan culture is considered as strategy orientation tool which managers purposely utilise in order to make stimulation of innovation activities in organisations. On the other hand, findings also indicate that hierarchical culture is less likely and may not be convenient for organisations which will develop innovations. Moreover, the data from the survey indicate that managers in organisations at the innovative processes more prefer to develop adhocracy culture because of this type of culture highlight an external and a flexibility orientation. In contrast, market culture seems like the appropriate type for aims of an innovative organisation. Accordance with this, these results support our hypotheses that organisational culture may be a crucial element for organisational ambidexterity since it affects significantly and positively the overall and its two dimensions.

Additionally, our findings show that the types of organisational culture dissimilarly can affect organisational ambidexterity and its strategies in a different manner. Thus, our findings show the discoveries of the Yu et al. (2014) where it signifies that different sort of organisational cultures such as adhocracy, clan, and market culture has a mutual relationship with technological innovation. Besides, their findings determine that adhocracy culture can be profitable for exploratory innovation; on the other hand, for exploitative one, clan culture is more appropriate. Thus, market culture is considered as coexisting variable among the exploratory and exploitative innovation. Moreover, the hierarchy culture is indicated as a component that inhibits product innovation. 
Moreover, the findings from North Macedonia and Turkey provide that organisational culture may be considered a determinative instrument in the exploitation and exploration activities of organisational ambidexterity. According to these findings, the gained outcomes of Lee et al. (2017) study prove that pro-innovation culture notably influences exploitation and exploration activities and also positively influences organisational ambidexterity. In general, it is argued that when one company decides to apply ambidexterity, it becomes ambidextrous as soon as the organisational culture becomes innovative. In other respects, Wang and Rafiq (2014) suggest that in case exploration and exploitation activities are appropriately managed inside a business unit, they may be considered as additional organisational activities rather than competitive activities in the innovation procedure. Additionally, Poškienè (2006) suggested that cultural values and norms are powerful tools to stimulate the process of innovation and creativity. Thus, the cultural influence on innovation and creativity depends more on the type of agreement rather than its existence.

Regarding this, Martinsen et al. (2015) suggest that when one firm develops a more innovative culture, the level of ambidexterity in the organisation will increase accordingly. They also suggest that while the organisation seeks for ambidexterity, the culture of the firm will develop more innovatively. Contrary to our findings, the outcomes of the Jaskyte and Dressler (2005), present that strong cultures may not be favourable for stimulating innovation strategy, especially given its content, for example, if the level of cultural values is higher on stability, predictability, security, working in collaboration with others, the level of innovative orientation may be less. Regarding this, Naranjo-Valencia et al. (2011) suggest that organisational culture determine the innovation process in the organisation. The studies also indicate that organisational culture may have an impact on the innovation strategy positively and negatively.

However, empirical evidence of this research suggests that these two components are interconnected with each other, and even though members of organisations come from the different culture, background, tradition, beliefs, values and families, they generally predict the same view about organisational culture on organisational ambidexterity. Thus, this means that employees in the work 
environment strive to fit into the culture of the organisation where they operate and try to be more innovative. Accordingly, Szczepańska-Woszczyna (2014) proposed that organisations which want to keep the level of innovations high should pay attention to some cultural feature, for instance, the manager should believe in their employees that they have abilities to try out new ideas. In this way, the employees gain the manager's support and feel independent while they operate innovative ideas. The results of the study additionally enhance that when managers give a clear signal that innovation is desirable and advantageous within the company, the employees will gather resources from outside and inside of organisations in order to establish better conditions for innovation. In sum, from the support of the hypothesis and considering that culture on the organisational environment is one of the factors that have a tremendous effect on the innovation process recently this relationship between two variables gains a good impact in national and international studies.

\subsection{Limitations of the Study}

This research involves some specific limitations, first of which is the fact that the survey is limited to two companies. Secondly, the body of the research includes sample which is limited to the food industry and in the limited geographic territory of Turkey and the Republic of North Macedonia. Thirdly, the perceptions of organisational culture to organisational ambidexterity were evaluated by all employees of the organisation. All these limitations well imply possibilities for future investigations in the areas of organisational culture and organisational ambidexterity.

\subsection{Future Recommendations}

Briefly speaking, additional comparative studies are required. This research recommends that future scholars should deeply investigate the relationship between organisational culture and organisational ambidexterity, in other industries, in other sectors, and other countries. In the business environment and innovation life cycle, leaders of organisations should encourage exploration and discovery in the early stages of services which they will offer to customers. While the services are determined, leaders of organisations should see that after the application process, particular efficiencies are exploited to produce results. Additionally, discoveries also 
suggest that leaders or managers of enterprises should consider the importance and the advantages of exploration and exploitation strategy in the order the organisations to balance the number of resources which are needed for their businesses to survive in the short-term and to be sustainable over the long-term. Hence, findings also suggest that a leader in creating sustainable organisations should possess items of organisational culture.

Finally, there has been scarce research on organisational culture determining the effects of organisational ambidexterity and its two sub-dimensions explorations and exploitation in employees of the food industry. In sum, this study contributes to this particular body of knowledge and future researchers might benefit from the theoretical, empirical way and the methods discussed in this study. 


\section{REFERENCES}

Ahmady, G. A., Nikooravesh, A., \& Mehrpour, M. (2016). Effect of Organizational Culture on Knowledge Management Based on Denison Model. Procedia-Social and Behavioral Sciences, 230, 387-395. Aktaş, E., Çiçek, I., \& Kıyak, M. (2011). The Effect of Organizational Culture on Organizational Efficiency: The Moderating Role of Organizational Environment and CEO Values. Procedia-Social and Behavioral Sciences, 24, 1560-1573.

Arditi, D., Nayak, S., \& Damci, A. (2017). Effect of Organizational Culture on Delay in Construction. International Journal of Project Management, 35(2), 136-147.

Attar, M. (2015). Üst Düzey Yöneticilerin Liderlik Özelliklerinin Örgütsel Ustalı Düzeyine Etkisi: Türk Bankacılık Sektörü Üzerine Bir Araştırma. Ankara: Gazi Kitabevi.

Barney, J. B. (1986). Organizational Culture: Can it be A Source of Sustained Competitive Advantage? Academy of Management Review, 11(3), 656-665.

Birkinshaw, J., \& Gupta, K. (2013). Clarifying the Distinctive Contribution of Ambidexterity to the Field of Organization Studies. The Academy of Management Perspectives, 27(4), 287-298.

Bodwell, W., \& Chermack, T. J. (2010). Organisational Ambidexterity: Integrating Deliberate and Emergent Strategy with Scenario Planning. Technological Forecasting and Social Change, 77(2), 193-202.

Büschgens, T., Bausch, A., \& Balkin, D. B. (2013). Organisational Culture and Innovation: A MetaAnalytic Review. Journal of Product Innovation Management, 30(4), 763-781.

Cameron, K., \& Freeman, S. J. (1991). Cultural Congruence, Strength, and Type: Relationships to Efffectiveness. Research in Organizational Change and Development, 5, 23-58.

Cameron, K., \& Quinn, R. E. (2006). Diagnosing and Changing Organizational Culture: Based on The Competing Values Framework: John Wiley \& Sons.

Chatman, J. A., \& O'Reilly, C. A. (2016). Paradigm lost: Reinvigorating The Study of Organizational Culture. Research in Organisational Behavior, 36, 199-224.

Chen, Y., Tang, G., Lee Cooke, F., \& Jin, J. (2016). How Does Executive Strategic Human Resource Management Link to Organizational Ambidexterity? An Empirical Examination of Manufacturing Firms in China. Human Resource Management, 55(5), 919-943.

Çömez, P., Erdil, O., Alpkan, L., \& Kitapçi, H. (2011). The Effects of Ambidexterity and Generative Learning on Innovative Firm Performance: The Moderating Effect of Transformational Leadership. Journal of Global Strategic Management 10, 76-89.

Dauber, D., Fink, G., \& Yolles, M. (2012). A Configuration Model of Organizational Culture. Sage Open, 2(1), 1-16.

Denison, D. R., \& Spreitzer, G. M. (1991). Organizational Culture and Organizational Development: A Competing Values Approach. Research in Organizational Change and Development, 5(1), 1-21.

Dubey, R., Gunasekaran, A., Helo, P., Papadopoulos, T., Childe, S. J., \& Sahay, B. (2017). Explaining The Impact of Reconfigurable Manufacturing Systems on Environmental Performance: The Role of Top Management and Organizational Culture. Journal of Cleaner Production, 141, 56-66.

Dunlap, D., Marion, T., \& Friar, J. (2013). The Role of Cross-National Knowledge on Organizational Ambidexterity: A Case of The Global Pharmaceutical Industry. Management Learning, 45(4), 1-19.

Fındıklı, M. A., \& Pınar, İ. (2014). Örgüt Kültürü Algısı ve Örgütsel Çift Yönlülük İlişkisi: Örgütsel Düzeyde Bilgi Paylaşımının Aracılık Etkisi. Yönetim ve Ekonomi: Celal Bayar Üniversitesi 21(1), 155-171.

Giritli, H., Oney-Yazici, E., Topcu-Oraz, G., \& Acar, E. (2006). Organizational Culture, A Comparative Analysis From The Turkish Construction Industry CCIM2006 Sustainable Development through Culture and Innovation, 26-29 November 2006 (pp. 1-9): UAE Dubai.

Gregory, B., Harris, S. G., Armenakis, A. A., \& Shook, C. L. (2009). Organisational Culture and Effectiveness: A Study of Values, Attitudes, and Organizational Outcomes. Journal of Business Research, 62(7), 673-679.

Günsel, A., Altındağ, E., Kılıç Keçeli, S., Kitapçı, H., \& Hızıroğlu, M. (2018). Antecedents and Consequences of Organizational Ambidexterity: the Moderating Role of Networking. Kybernetes, 47(1), 186-207.

Hair, J. F., Black, W. C., Babin, B. J., Anderson, R. E., \& Tatham, R. (2006). Multivariate data analysis . Uppersaddle River: NJ: Pearson Prentice Hall.

Hartnell, C. A., Ou, A. Y., \& Kinicki, A. (2011). Organizational Culture and Organizational Effectiveness: A Meta-Analytic Investigation of The Competing Values Framework's Theoretical Suppositions. Journal of Applied Psychology, 96(4), 677-694. 
Hofstede, G. (1983). The Cultural Relativity of Organizational Practices and Theories. Journal of International Business Studies, 14(2), 75-89.

Hofstede, G. (1993). Cultural Constraints in Management Theories. The Academy of Management Executive, 7(1), 81-94.

Hofstede, G. (1998). Attitudes, Values and Organisational Culture: Disentangling the Concepts. Organisation Studies, 19(3), 477-493.

Hofstede, G., \& Bond, M. H. (1984). Hofstede's Culture dimensions: An Independent Validation Using Rokeach's Value Survey. Journal of Cross-Cultural Psychology, 15(4), 417-433.

Hofstede, G., Hofstede, G. J., \& Minkov, M. (2010). Cultures and Organisations: Software of the Mind (Third Edition ed.): McGRAW-HILL

Hogan, S. J., \& Coote, L. V. (2014). Organizational Culture, Innovation, and Performance: A Test of Schein's Model. Journal of Business Research, 67(8), 1609-1621.

Jaskyte, K., \& Dressler, W. W. (2005). Organisational Culture and Innovation in Nonprofit Human Service Organizations. Administration in Social Work, 29(2), 23-41.

Klimas, P. (2016). Organizational Culture and Coopetition: An Exploratory Study of The Features, Models and Role in The Polish Aviation Industry. Industrial Marketing Management, 53, 91-102.

Koryak, O., Lockett, A., Hayton, J., Nicolaou, N., \& Mole, K. (2018). Disentangling the Antecedents of Ambidexterity: Exploration and Exploitation. Research Policy, 47(2), 413-427.

Larentis, F., Antonello, C. S., \& Slongo, L. A. (2018). Organizational Culture and Relationship Marketing: An Interorganizational Perspective. Revista Brasileira de Gestão de Negócios, 20(1), 37-56.

Lee, \& Kramer, A. (2016). The Role of Purposeful Diversity and Inclusion Strategy (PDIS) and Cultural Tightness/Looseness in The Relationship Between National Culture and Organizational Culture. Human Resource Management Review, 26(3), 198-208.

Lee, Woo, H.-G., \& Joshi, K. (2017). Pro-Innovation culture, Ambidexterity and New Product Development Performance: Polynomial Regression and Response Surface Analysis. European Management Journal, 35(2), 249-260.

Lee, J., Shiue, Y.-C., \& Chen, C.-Y. (2016). Examining The Impacts of Organizational Culture and Top Management Support of Knowledge Sharing on The Success of Software Process Improvement. Computers in Human Behavior, 54, 462-474.

Lin, H.-E., \& McDonough III, E. F. (2011). Investigating the Role of Leadership and Organizational Culture in Fostering Innovation Ambidexterity. IEEE Transactions on engineering management, 58(3), 497 509.

Lu, V. N., Plewa, C., \& Ho, J. (2016). Managing Governmental Business Relationships: The Impact of Organisational Culture Difference and Compatibility. Australasian Marketing Journal (AMJ), 24(1), 93100.

Lubatkin, M. H., Şimşek, Z., Ling, Y., \& Veiga, J. F. (2006). Ambidexterity and Performance in Small-to Medium-Sized Firms: The Pivotal Role of Top Management Team Behavioral Integration. Journal of Management, 32(5), 646-672.

Maitland, A., Hills, L., \& Rhind, D. (2015). Organisational Culture in Sport-A Systematic Review. Sport Management Review, 18(4), 501-516.

Marín, G. S., Hernández, A. J. C., del Valle, I. D., \& Castillo, M. Á. S. (2016). Organizational Culture and Family Business: A Configurational Approach. European Journal of Family Business, 6(2), 99-107.

Martinsen, L., Enger, Ø., \& Tømmervik, E. (2015). How Ambidextrous Is Your Company's Culture? , NTNU. Nakip, M. (2013). SPSS Destekli Pazarlama Araştırmalarana Giriş (4 ed.). Ankara: Seçkin Yayıncılık.

Naranjo-Valencia, J. C., Jiménez-Jiménez, D., \& Sanz-Valle, R. (2011). Innovation or Imitation? The Role of Organizational Culture. Management Decision, 49(1), 55-72.

Naranjo Valencia, J. C., Jiménez-Jiménez, D., \& Sanz-Valle, R. (2016). Studying The Links Between Organizational Culture, Innovation, and Performance in Spanish Companies. Revista Latinoamericana de Psicología, 48(1), 30-41.

Nunnally, J. C. (1978). Psychometric Theory: 2d Ed: McGraw-Hill.

O'Reilly, C. A., Chatman, J., \& Caldwell, D. F. (1991). People and Organizational Culture: A Profile Comparison Approach to Assessing Person-Organization Fit. Academy of Management Journal, 34(3), 487 516.

O'Reilly, C. A., \& Tushman, M. L. (2008). Ambidexterity as a Dynamic Capability: Resolving The Innovator's Dilemma. Research in Organisational Behavior, 28, 185-206.

Panagopoulos, G. (2016). Aspects of Organizational Ambidexterity Journal of Global Strategic 
Management, 10(1), 5-15.

Pellegrinelli, S., Murray-Webster, R., \& Turner, N. (2015). Facilitating Organizational Ambidexterity Through the Complementary Use of Projects and Programs. International Journal of Project Management, 33(1), 153-164.

Poškienè, A. (2006). Organizational Culture and Innovations. Engineering Economics, 46(1), 45-50.

Raisch, S., Birkinshaw, J., Probst, G., \& Tushman, M. L. (2009). Organisational Ambidexterity: Balancing Exploitation and Exploration for Sustained Performance. Organisation science, 20(4), 685-695.

Rosing, K., Frese, M., \& Bausch, A. (2011). Explaining the Heterogeneity of the Leadership-Innovation Relationship: Ambidextrous Leadership. The Leadership Quarterly, 22(5), 956-974.

Rovithis, M., Linardakis, M., Merkouris, A., Patiraki, E., Vassilaki, M., \& Philalithis, A. (2017). Organizational Culture Among Levels of Health Care Services in Crete (Greece). Applied Nursing Research, 36, 9-18.

Sánchez-Marín, G., Danvila-del Valle, I., \& Sastre-Castillo, Á. (2015). Entrepreneurship and Family Business: Does The Organization Culture Affect to Firm Performance? New Challenges in Entrepreneurship and Finance (pp. 169-179): Springer.

Schein, E. (1988). Organizational Culture. Sloan School of Management, MIT, 1-50.

Schein, E. (2009). The Corporate Culture Survival Guide (Vol. 158): John Wiley \& Sons.

Siachou, E., \& Gkorezis, P. (2018). Empowering Leadership and Organisational Ambidexterity: A Moderated Mediation Model. Paper presented at the Evidence-based HRM: a Global Forum for Empirical Scholarship.

Şimşek. (2009). Organisational Ambidexterity: Towards a Multilevel Understanding. Journal of Management Studies, 46(4), 597-624.

Şimşek, Özgener, Ş., Kaplan, M., \& Ulu, S. (2010). Strategic intent, Organizational Ambidexterity and Performance: A Test of the Moderating Role of Perceived Environmental Uncertainty. Proceedings of $6 \mathrm{th}$ International Strategic Management Conference 273-286.

Strese, S., Meuer, M. W., Flatten, T. C., \& Brettel, M. (2016). Examining Cross-Functional Coopetition as a Ariver of Organizational Ambidexterity. Industrial Marketing Management, 57, 40-52.

Sulphey, M. M., \& Alkahtani, N. S. (2017). Organisational Ambidexterity as a Prelude to Corporate Sustainability Journal of Security E Sustainability Issues, 7(2), 335-347.

Szczepańska-Woszczyna, K. (2014). The Importance of Organizational culture for Innovation in the Company. Forum Scientiae Oeconomia, 2(3), 27-39.

Urban, W. (2015). The Lean Management Maturity Self-Assessment Tool Based on Organizational Culture Diagnosis. Procedia-Social and Behavioral Sciences, 213, 728-733.

Vahlne, J.-E., \& Jonsson, A. (2017). Ambidexterity as a Dynamic Capability in the Globalisation of the Multinational Business Enterprise (MBE): Case Studies of AB Volvo and IKEA. International Business Review, 26(1), 57-70.

Vukonjanski, J., \& Nikolić, M. (2013). Organizational Culture and Job Satisfaction: The Effects of Company's Ownership Structure. Journal Of Engineering Management And Competitiveness (JEMC), 3(2), 41-49.

Wang, C. L., \& Rafiq, M. (2014). Ambidextrous Organisational culture, Contextual Ambidexterity and New Product Innovation: A Comparative Study of UK and Chinese High-Tech Firms. British Journal of management, 25(1), 58-76.

Warrick, D. D. (2017). What Leaders Need to Know About Organizational Culture. Business Horizons, 60(3), 395-404.

Wei, Y., \& Miraglia, S. (2017). Organizational Culture and Knowledge Transfer in Project-Based Organisations: Theoretical Insights From a Chinese Construction Firm. International Journal of Project Management, 35(4), 571-585.

Yazıcıoğlu, Y., \& Erdoğan, S. (2004). Spss Uygulamalı Bilimsel Araştırma Yöntemleri. Ankara Detay Yayıncilik.

Yilmaz, C., \& Ergun, E. (2008). Organizational Culture and Firm Effectiveness: An Examination of Relative Effects of Culture Traits and The Balanced Culture Hypothesis in an Emerging Economy. Journal of World Business, 43(3), 290-306.

Yu, R., He, J., \& Liu, Z. (2014). The Co-Evolution of Organizational Culture Transformation and Ambidextrous Capability: A Strategic Orientation Perspective. Journal of Advanced Management Science Vol, 2(2). 